\title{
Analisis Perilaku Malware Dengan Metode Surface Analysis Dan Runtime Analysis
}

\author{
Ahmad Siddiq ${ }^{1}$, Helda Yudiastuti ${ }^{2}$, Febriyanti Pajaitan*3 \\ 1,3Informatics Departement, Bina Darma University, Palembang, Indonesia \\ ² Vocational Departement, Bina Darma University, Palembang, Indonesia \\ Email: ahmadsiddiq96.as@gmail.com¹, helda.yudiastuti@binadarma.ac.id², \\ febriyanti_panjaitan@binadarma.ac.id ${ }^{3}$
}

\begin{abstract}
Abstrak
Saat ini penggunaan komputer sudah menjadi hal yang biasa baik oleh pegawai, mahasiswa dan anak-anak sekolah. Umumnya sistem operasi yang digunakan adalah Windows, oleh karena kemudahan, namun hal ini juga memberikan peluang bagi orang-orang yang memiliki niat buruk untuk mengambil keuntungan secara ilegal dengan berbagai macam cara, salah satunya dengan membuat sebuah Malware yang disusupkan dalam sebuah program atau dengan cara-cara lainnya. Berdasarkan hal tersebut penulis ingin meneliti perilaku apa saja yang dilakukan oleh Malware ketika menyerang sebuah system operasi khususnya Windows menggunakan metode Surface Analysis dan Runtime Analysis untuk. Dengan menggunkan metode ini, informasi yang didapat berupa jenis file asli yang di periksa, ukuran file sebenarnya dan melihat apakah ada file lain di dalam file yang di periksa. Dari pemeriksaan menggunakan metode ini juga didapatkan hash function atau MD5 yang merupakan identitas unik dari file yang di periksa serta dapat memeriksa secara keseluruhan seperti proses yang berjalan di komputer, dan peristiwa janggal lainnya yang biasa terjadi saat komputer terinfeksi Malware. Sehingga nantinya dapat diklasifikasikan kedalam Malware jenis apa.
\end{abstract}

Kata Kunci: Windows, Malware, Surface Analysis, Runtime Analysis

\section{PENDAHULUAN}

Di era digitalisasi saat ini, komputer seolah sudah menjadi suatu hal yang wajib ada dalam berbagai instansi, baik pemerintah maupun swasta, akademik dan juga industri telah menjadikannya sebagai media input dan output data dan informasi, sehingga komputerisasi memegang peranan penting dalam pengolahan data. Komputerisasi memberikan efisiensi waktu dan efektivitas keamanan data yang lebih baik dibandingkan dengan cara 


\section{Journal of Software Engineering Ampera}

Vol. 1, No. 3, October 2020 e-ISSN: 2775-2488

https://journal-computing.org/index.php/journal-sea/index

manual. Namun ini juga memberikan kesempatan bagi orang-orang yang berniat buruk untuk memanipulasi data dan informasi tersebut, seperti mencuri data, membajak akun dan lain sebagainya. Hampir dari setiap kejahatan tersebut melibatkan sebuah Malware (Malicius Software) atau bisa juga disebut dengan Program jahat (Adenansi dan Novarina, 2017) [1]. Semakin hari perkembangan Malware semakin mutakhir dan kompleks, pembuat Malware selalu melakukan perubahan guna mencari-cari celah keamanan dengan membuat banyak varian pada pola serangannya (Perdhana, 2011) [5]. Dari itu pengguna sistem komputer harus lebih waspada dan berhati-hati, terlebih pada pengguna platfom Windows dan MAC.

Masuknya sebuah malware ke dalam system dapat melalui berbagai macam cara, seperti disisipkan pada sebuah file atau aplikasi tertentu, sehingga korban tidak menyadari bahwa komputernya telah disusupi sebuah malware. Hal inilah yang melatar belakangi saya sebagai penulis untuk meneliti perilaku dari Malware tersebut, agar dapat mengetahui pola serangan dan aktivitasnya sehingga nantinya dapat dikelompokkan berdasarkan pola-pola sebuah Malware. Untuk dapat menganalisis apakah sebuah file terdapat Malware didalamnya atau file itu sendiri merupakan sebuah Malware dan juga mengetahui apakah sebuah komputer telah terserang Malware, dapat menggunakan beberapa macam metode, di antaranya metode Surface analysis dan Runtime analysis. Dengan menggunakan kedua metode ini, kita mampu mendapatkan informasi dari sebuah Malware, seperti jenis file dan tipe serangannya.

Metode Surface analysis merupakan sebuah metode yang digunakan untuk menganalisis bagian luar dari sebuah file, dari pemeriksaan tersebut memberikan informasi berupa jenis file asli yang di periksa, ukuran file sebenarnya dan melihat apakah ada file lain di dalam file yang di periksa. Metode ini juga mampu memberikan informasi yang cukup akurat dalam mengetahui Malware yang menyamar atau bersembunyi di dalam file lain. Dari pemeriksaan menggunakan metode ini juga didapatkan hash function atau fingerprint (MD5, SHA-1) yang merupakan identitas unik dari file yang di periksa. Metode Runtime analysis, sesuai dengan namanya metode ini akan menjalankan atau mengaktifkan file yang di periksa untuk mendapatkan informasi mengenai kegiatan apa saja yang di lakukan Malware saat berhasil menginfeksi sebuah komputer. Pada tahap ini, komputer akan di periksa secara keseluruhan seperti proses yang berjalan di komputer, perubahan 


\section{Journal of Software Engineering Ampera}

Vol. 1, No. 3, October 2020 e-ISSN: 2775-2488

https://journal-computing.org/index.php/journal-sea/index

registry, aktivitas komunikasi internet dan peristiwa janggal lainnya yang biasa terjadi saat komputer telah terinfeksi Malware (Agung, 2011) [2].

\section{METHODS}

\section{1. Metode Penelitian}

Metode penelitian yang digunakan adalah metode kualitatif yaitu data yang didapat dari membaca informasi, mengamati objek, dan wawancara (Sugiyono, 2009:19) [6]. Sumber data yang digunakan terdiri dari dua bagian yaitu primer dan sekunder. Data primer didapat dengan melakukan kegiatan membaca informasi, mengamati aktivitas objek, dan bertanya kepada bagian IT. Data sekunder diperoleh dengan membaca pustaka yang berhubungan dengan segala hal yang akan diteliti serta mendokumentasikan kebutuhan yang ada pada obejk penelitian.

\section{2. Metode Analisis}

Metode yang di gunakan dalam penelitian ini adalah Surface analysis dan Runtime analysis. Menurut Richardus Eko Indrajit selaku ketua dari Lembaga Indonesia Security Incident Response Team On Internet Infrastructure (IDSIRTII) periode 2010, mengatakan bahwa kedua metode ini merupakan pendekatan yang umum digunakan untuk mendeteksi apakah program tersebut merupakan klasifikasi jenis malware atau bukan. Dengan perpaduan kedua metode tersebut, peneliti juga dapat mengetahui dengan baik bagaimana aktivitas malware dalam sebuah sistem.

Menurut Indrajit (2012) [3], Surface Analysis adalah suatu kajian pendeteksian malware dengan mengamati sekilas ciri-ciri khas sebuah file program tanpa harus mengeksekusinya. Untuk melihat ciri khas tersebut dapat dilakukan dengan menggunakan bantuan software atau perangkat aplikasi pendukung. Analisa ini memiliki ciri-ciri sebagai berikut :

1) Program yang dikaji tidak akan dijalankan, hanya akan dilihat "bagian luarnya" saja (sebagai analogi selayaknya orang yang ingin membelibuah-buahan, untuk mengetahui apakah buah yang bersangkutan masih mentah atau sudah busuk cukup dengan melihat permukaan kulitnya, membauhinya, dan meraba-raba teksturnya atau struktur kulitnya). Dari sini akan dicoba ditemukan hal-hal yang patut 


\section{Journal of Software Engineering Ampera}

Vol. 1, No. 3, October 2020 e-ISSN: 2775-2488

https://journal-computing.org/index.php/journal-sea/index

untuk dicurigai karena berbeda dengan cirikhas program kebanyakan yang serupa dengannya; dan

2) Sang pengkaji tidak mencoba untuk mempelajari "source code" program yang bersangkutan untuk mempelajari algoritma maupun struktur datanya (sebagaimana layaknya melihat sebuah kotak hitam atau "black box".

Runtime analysis pada dasarnya ada kesamaan antara runtime analysis dan surface analysis, yaitu keduanya sama-sama berada dalam ranah mempelajari ciri-ciri khas yang selayaknya ada pada sebuah program yang normal. Bedanya adalah bahwa runtime analysis, dipersiapkan sebuah prosedur dan lingkungan untuk mengeksekusi atau menjalankan programnya yang dicurigai mengandung atau sebagai malware tersebut. Model analisa ini menghasilkan kajian yang lebih mendalam karena selain dihilangkannya proses "mendugaduga", dengan mengeksekusi malware dimaksud akan dapat dilihat "perilaku" dari program dalam menjalankan "skenario jahatnya" sehingga selanjutnya dapat dilakukan analisa dampak terhadap sistem yang ada.

Menurut (Nurdiyanto, 2013) [4] dalam buku "practical malware analysis", malware dibagi menjadi 9 kelompok sedangkan berdasarkan sasaran serangannya, malware dibagi menjadi dua kelompok.

1) Backdoor adalah jenis malware yang menyusup ke sebuah sistem (login) dengan ilegal dan tidak normal tanpa diketahui.

2) Botnet dalah jenis yang memberikan akses pada penyerang untuk memberikan instruksi pada setiap komputer yang terkena sesuai keinginannya melalui server.

3) Downloader jenis ini adalah perilaku malware yang dapat mendownload software jahat lainnya dan menginstalasinya, sehingga penyerang mampu mendapatkan berbagai informasi dari korban.

4) Information-stealing Malware perilaku Malware ini mampu mengumpulkan informasi dari korban dan mengirimkannya kepada pelaku.

5) Launcher perilaku jenis ini digunakan pelaku untuk menjalankan program lainnya untuk mendapatkan informasi lebih dalam dari korban.

6) Rootkit digunakan keberadaan kode lainnya agar pelaku dapat mengakses komputer dari jarak jauh tanpa diketahui.

7) Scareware adalah sebuah tipuan dari pelaku, untuk mendapatkan keuntungan dengan menawarkan sesuatu yang memaksa korban membeli produknya, seperti mengatakan bahwa komputer korban 


\section{Journal of Software Engineering Ampera}

Vol. 1, No. 3, October 2020 e-ISSN: 2775-2488

https://journal-computing.org/index.php/journal-sea/index

telah terserang virus, dan virus itu hanya dapat diatasi dengan antivirus buatannya, padahal kenyataannya program itu hanya menghapus Scareware itu sendiri.

8) Spam-sending Malware teknik ini di gunakan pelaku untuk mengirimkan spam pada komputer korbannya dengan cara menginfeksi sistemnya.

9) Worm atau Virus adalah jenis yang dapat menggandakan dirinya sendiri tanpa perlu bergantung pada program lain, ia dapat menyebar dengan cepat dan masuk ke dalam jaringan komputer melalui port layanan yang terbuka.

\section{3. Metode Pengumpulan Data}

Metode pengumpulan data dalam penelitian ini yaitu :

1) Studi Pustaka (Literature Review), Dengan menggunakan metode ini, penulis melakukan pencarian dan pembacaan tentang buku-buku, majalah atau referensi yang berhubungan dengan malware, analisa malware, Honeypot dan lain-lain.

2) Wawancara, Wawancara dilakukan dengan beberapa pihak yang terkait dengan penggunaan Sitem Operasi windows, di antaranya Admin PT. Taysir di kota Palembang dan beberapa pengguna di lingkungan Universitas Binadarma Palembang untuk mendapatkan data mengenai dampak dan perilaku malware apa saja yang mereka temukan ketika terserang sebuah maware.

\section{HASIL DAN PEMBAHASAN}

\subsection{Surface Analysis}

Dalam metode ini, peneliti akan melihat dan mengidentifikasi unsur-unsur yang terdapat di dalam sebuah file yang dicurigai sebagai malware.

\section{1) File Atrribute Analysis}

Pada tahapan ini kita berhasil mendapatkan atribut dari sample dengan tipe executable pada sistem 32-bit dan "MD5(AD84220B21FAA7F98ECC05C504ACD7B7)". Selanjutnya kita dapat melihat indikators yang dihasilkan oleh pestudio dengan menggunakan angka 1 sampai 9 sebagai alamatnya. Angka 1 dan 2 menunjukan bahwa file tersebut memiliki tingkat bahaya yang cukup tinggi, karena memiliki kemampuan yang 


\section{Journal of Software Engineering Ampera}

Vol. 1, No. 3, October 2020 e-ISSN: 2775-2488

https://journal-computing.org/index.php/journal-sea/index

biasanya ada pada sebuah malware, seperti memodifikasi registry dan terdapat blacklist pada stringnya yaitu melakukan perubahan pada file, menghapus serta merusak. (Agung, 2011). Maka, semakin banyak angka 1 dan 2, maka semakin besar pula kemungkinan file tersebut merupakan sebuah malware. Didapati pada file Games.exe terdapat 5 dari 11 indikators yang menunjukan bahwa file tersebut kemungkinan merupakan file yang berbahaya.

\section{2) Fuzzy Hashing}

Untuk mengidentifikasi keaslian dari malware yang akan dianalisa, kedua file kita letakkan dalam satu folder yang sama untuk memudahkan pencocokan md5 dan hash diantara keduanya. Terlihat pada gambar dibawah menunjukan bahwa md5 dan hash memiliki nilai kesamaan 100\%, hal ini menunjukan bahwa file yang akan kita analisa nantinya sama persis dengan file asli.

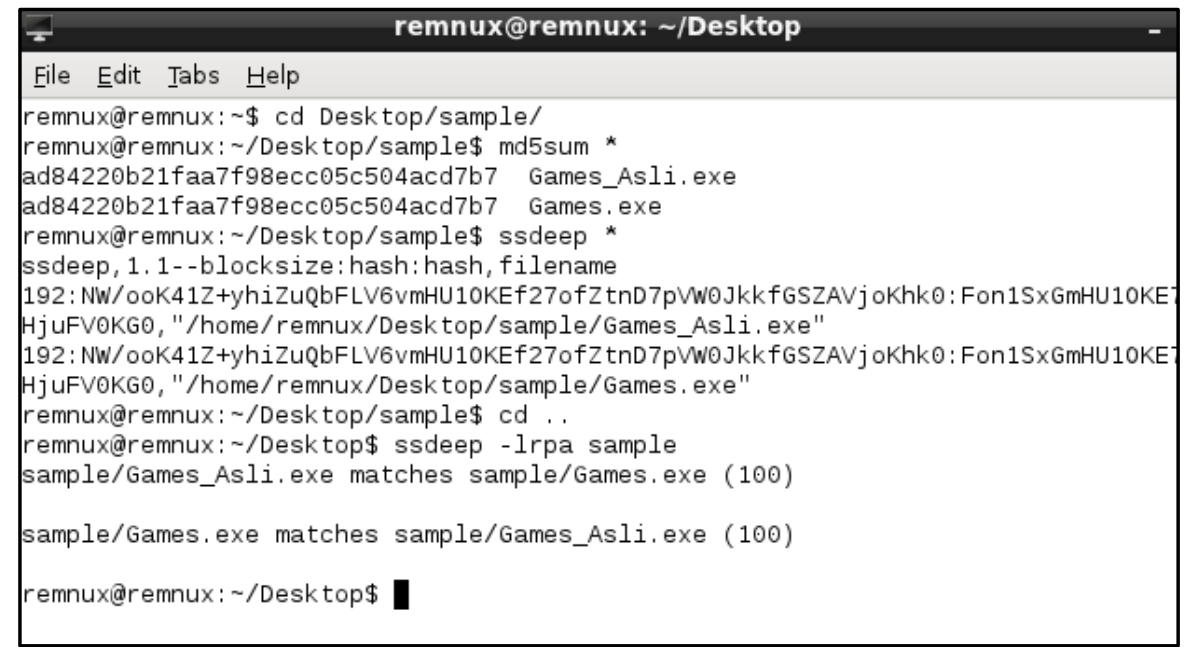

Gambar 2. Fuzzy Hasing file sempel

\section{3) Packer Chack}

Penting untuk kita mengetahui apakah file tersebut telah di pucking atau tidak oleh pembuatnya karena strings pada file yang telah di packing akan terenkripsi sehingga dapat mempersulit analisa nantinya. Terlihat pada gambar di bawah ini yang menunjukan bahwa file dikompres atau packing, maka sebelum mulai melakukan analisa ke tahap selanjutnya file harus di unpacking untuk dapat melihat srting yang ada pada file tersebut. 


\section{Journal of Software Engineering Ampera}

Vol. 1, No. 3, October 2020 e-ISSN: 2775-2488

https://journal-computing.org/index.php/journal-sea/index

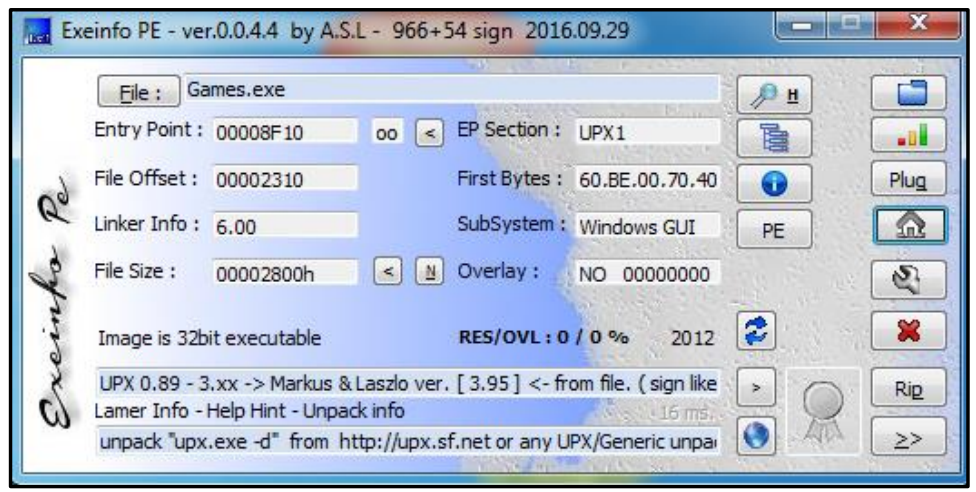

Gambar 3. Hasil Packers Chack file Games.exe dengan Exeinfo PE

Untuk melakukan unpacking kita harus mengetahui tool apa yang digunakan untuk packing pada file tersebut, informasi yang didapat dari Exeinfo bahwa tool yang digunakan adalah UPX 0.89 maka kita harus mendownloadnya terlebih dahulu, pada lamer info terdapat informasi bahwa tool bisa didapatkan dialamat http://upx.sf.net. Setelah tool didapat maka kita akan menjalankannya melalui Commend Prompt (CMD) dengan menempatkan file satu folder bersama tool.

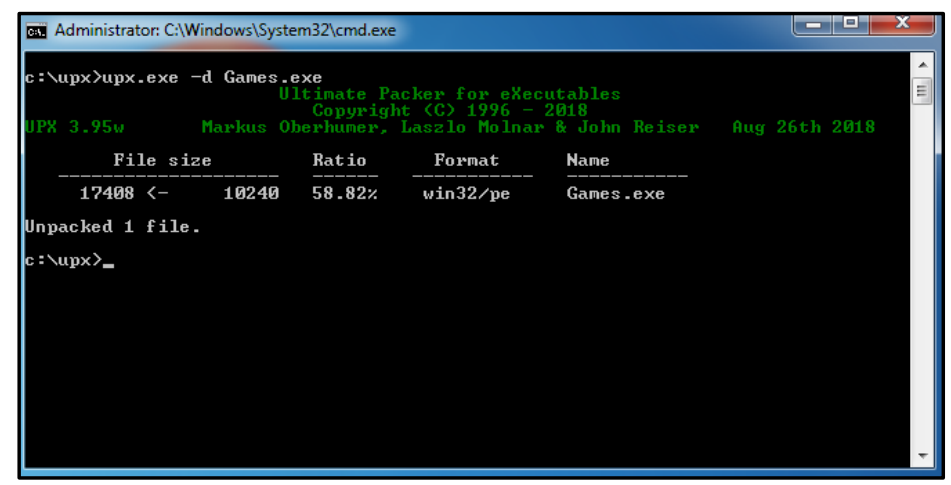

Gambar 5. Hasil Unpacking.

File PE yang berisi Header dan beberapa bagian yang penting. Di bawah ini merupakan keterangan dari gambar di atas:

a) .text : Pada bagian ini berisikan kode yang dapat di eksekusi

b) .rdata : Bagian ini menampung dan membaca data yang dapat diakses secara global

c) data : Menyimpan data global yang dapat diakses hanya melalui program saja 


\section{Journal of Software Engineering Ampera}

Vol. 1, No. 3, October 2020 e-ISSN: 2775-2488

https://journal-computing.org/index.php/journal-sea/index

\section{4) String analysis}

Tool yang kita gunakan selanjutnya yaitu Yara untuk menganalisa keberadaan string pada file. Dengan menggunakan aturan ini kita akan melihat ada berapa string yang didapatkan oleh Yara Rule. Semakin banyak string yang didapatkan maka semakin besar kemungkinan file merupakan sebuah malware karena aturan yang ada pada yara rule mampu membaca string pada program.

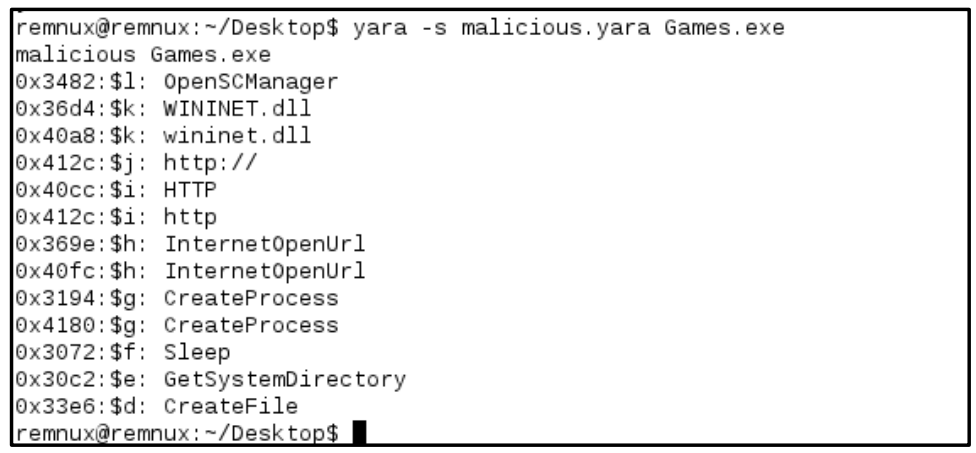

Gambar 5. Hasil Yara Rule.

Analisa strings, pada tahap ini penulis mendapatkan hasil dengan menggunakan Pestudio yaitu terdapat 101 string yang terbaca pada file tersebut dari 272 yang ada. Terlihat adanya sebuah alamat web yaitu wWw.1535ss.com, ini membuktikan adanya interaksi dari program untuk mengakses ke jaringan internet. Penulis juga menggunakan dua tool yang ada pada sistem operasi remnux yaitu yara dan strings, hasil dari kedua tool ini menampilkan adanya string yang biasa dimiliki oleh sebuah malware. Hasil yang didapat dengan menggunakan ketiga tools berupa string yang biasanya terdapat dalam sebuah malware diantaranya :

a) GetSystemDirectory, digunakan untuk membuka penyimpanan pada sistem

b) DeleteFile, digunakan untuk menghapus file

c) Sleep, digunakan untuk memberikan perintah masuk ke mode tidur pada sistem, hal ini memungkinkan adanya kontrol jarak jauh dari file tersebut

d) InternetOpenUr, digunakan untuk dapat terhubung ke beberapa server eksternal untuk mengunduh sesuatu

e) HTTP, ini digunakan untuk memanggil sebuah laman web 


\section{Journal of Software Engineering Ampera}

Vol. 1, No. 3, October 2020 e-ISSN: 2775-2488

https://journal-computing.org/index.php/journal-sea/index

f) WININET.dll, merupakan modul yang didalamnya terdapat instruksi InternetOpenUr yang digunakan untuk dapat terhubung kesebuah layanan server.

g) OpenSCManager, untuk membentuk koneksi ke manajer kontrol layanan pada komputer yang ditentukan dan membuka database pengelola kontrol layanan yang ditentukan.

\section{5) Malware Scan}

Pada tahap ini terlihat hasil scan dari sample menunjukan bahwa file belum terdeteksi sebagai sebuah malware melalui md5 ketika file sudah dibongkar, dari itu kita akan mencari tau lebih banyak pada metode selanjutnya dengan cara mengeksekusi file. Namun setelah file di Upload maka virus total menampilkan informasi bahwa 53 dari 70 anti virus menyatakan file tersebut merupakan sebuah malware dengan jenis worm dan trojan. Perilaku dari program ini yaitu mencoba untuk melakukan komunikasi melalui jaringan ke alamat www.1535ss.com, membuat file baru pada system32 yang merupakan pusat file system pada sistem operasi windows.

\subsection{Runtime Analysis}

Pada tahap ini kita akan menjalankan file yang akan kita Analisa untuk melihat aktivitas apa saja yang dilakukannya, sehingga kita dapat menilai apakan file tersebut merupakan malware atau bukan.

\section{1) Melihat perubahan Registry dengan Regshot}

Dengan menggunakan Regshot kita dapat melihat perubahan yang terjadi pada regitry setelah file dijalankan. Terlihat file melakukan beberpa perubahan dengan menambahkan beberapa file registry berupad "HKLMISYSTEM|ControlSet001|services|WinHmks32".

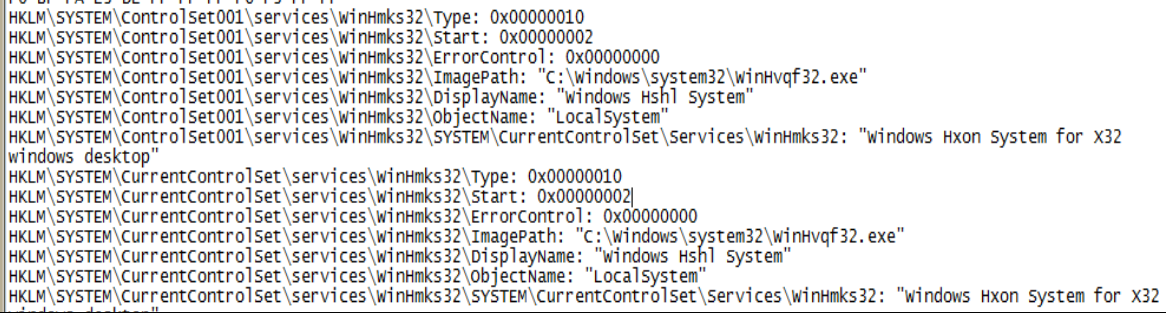

Gambar 6. Hasil monitoring Rigshot 


\section{Journal of Software Engineering Ampera}

Vol. 1, No. 3, October 2020 e-ISSN: 2775-2488

https://journal-computing.org/index.php/journal-sea/index

2) Melihat semua aktivitas aplikasi pada sistem dengan Process Hacker

Aplikasi ini akan memeriksa semua file yang sedang berjalan di dalam sistem, mirip seperti Task Manager yang ada di windows, namu lebih jelas dan rinci. Terliha pada Proses Hacker adanya proses svchost.exe ketika file Games.exe di eksekusi. Ketika file svchost.exe kita Terminate, maka terlihat pada wireshark layanan yang meminta akses ke www.1535ss.com berhenti.

\begin{tabular}{|c|c|c|c|c|c|c|}
\hline T-1 sppsycexe & 3328 & & & $4.97 \mathrm{MB}$ & N UNFTWORK SERUTCF & 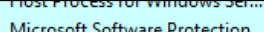 \\
\hline WmiApSrvexe & 2816 & 0.04 & & $1.13 \mathrm{MB}$ & NT AUTHORITY SYSTEN & WMI Performance Reverse Ad... \\
\hline GoogleUpdate.exe & 3652 & & & $3.23 \mathrm{MB}$ & NT AUTHORTMSYSTEN & Google Installer \\
\hline (1-1) TrustedInstaller.exe & 3808 & 56.33 & $6.49 \mathrm{kB} / \mathrm{s}$ & $7.21 \mathrm{MB}$ & NT AUTHORIT SYSTEN & Windows Modules Installer \\
\hline [1:-1 Isass.exe & 500 & 0.63 & & $2.25 \mathrm{MB}$ & NT AUTHORITYSYSTEN & Local Security Authority Proce... \\
\hline III Ism.exe & 508 & & & $1.05 \mathrm{MB}$ & NT AUTHORITYSYSTEN & Local Session Manager Service \\
\hline (1) csrss.exe & 396 & 0.20 & $264 \mathrm{~B} / \mathrm{s}$ & $4.17 \mathrm{MB}$ & NT AUTHORITYSYSTEN & Client Server Runtime Process \\
\hline 4. winlogon.exe & 432 & & & $1.67 \mathrm{MB}$ & NT AUTHORITY SYSTEN & Windows Logon Application \\
\hline$\Delta$ explorer.exe & 1608 & 2.47 & & $30.36 \mathrm{MB}$ & WIN-5KH88ATFUEB\Use & Windows Explorer \\
\hline vin vmtoolsd.exe & 1932 & 0.30 & $1.79 \mathrm{kB} / \mathrm{s}$ & $11.71 \mathrm{MB}$ & WIN-5KH88ATFUEB $\backslash$ Use & VMware Tools Core Service \\
\hline ProcessHacker.exe & 3056 & 2.06 & & $6.82 \mathrm{MB}$ & WIN-5KH88ATFUEB\Use & Process Hacker \\
\hline [1] svchost.exe & 1892 & 0.16 & & $0.98 \mathrm{MB}$ & NT AUTHORITYSYSTEN & Host Process for Windows Ser... \\
\hline CPU Usage: $100.00 \%$ Physical me & $31 \mathrm{G}$ & $5.39 \%)$ & Processes: 45 & & & \\
\hline
\end{tabular}

Gambar 7. Proses yang berjalan di latar belakang sistem

3) Melihat aktivitas malware di dalam sebuah jaringan menggunakan CaptureBAT

Dengan menggunakan CaptureBAT kita akan melihat perilaku dari file Games.exe setelah file tersebut dieksekusi. Install file CaptureBAT pada windows, selanjutnya ia akan meminta untuk restart, setelah itu buaka cmd dan ketikan "cd C:|Program FilelCapture|CaptureBAT.exe" maka tool akan aktif, selanjutnya kita juga persiapkan Wireshark pada remnux untuk melihat paket data yang berjalan selama proses Analisa berlangsung pada captureBAT. Eksekusi file Games.exe dengan cara klik kanan, Run Administrator, dan tunggu beberapa saat sambill melakukan beberapa aktivitas seperti mengetikan sesuatu di notepade untuk melihat kemungkinan adanya keylog yang dilakukan, Selanjutnya matikan captureBAt dengan mengklik enter, maka ia akan menyimpan hasil capture secara otomatis di "C:|Program FilelCapturel" dalam bentuk "capture_11102018_1056.zip".

\section{4) Analisa menggunakan Noriben Malware Analysis Sandbox}

Noriben bekerjasama dengan procmon dalam memonitoring aktivitas yang terjadi dalam system, sehingga kita perlu meletakkan file procmon dalam satu 


\section{Journal of Software Engineering Ampera}

Vol. 1, No. 3, October 2020 e-ISSN: 2775-2488

https://journal-computing.org/index.php/journal-sea/index

folder. Tempatkan sempel malware di desktop agar mudah ditemukan, dan selanjutnya kita mengecek alamat IP yang ada pada Windows, jika semua sudah selesai maka kita beralih ke system operasi Remnux untuk menjalankan wireshark yang nantinya akan memonitoring semua lalulintas jaringan dengan ditambah sebuah perangkat lunak Inetsim untuk memanipulasi jaringan local sehingga seakan-akan seperti berjalan pada jaringan internet. Jika semua telah selesai maka jalankan Noriben dan tunggu sampai dalam keadaan runtime complete. Jalankan malware dengan memberikan hak akses administrator.

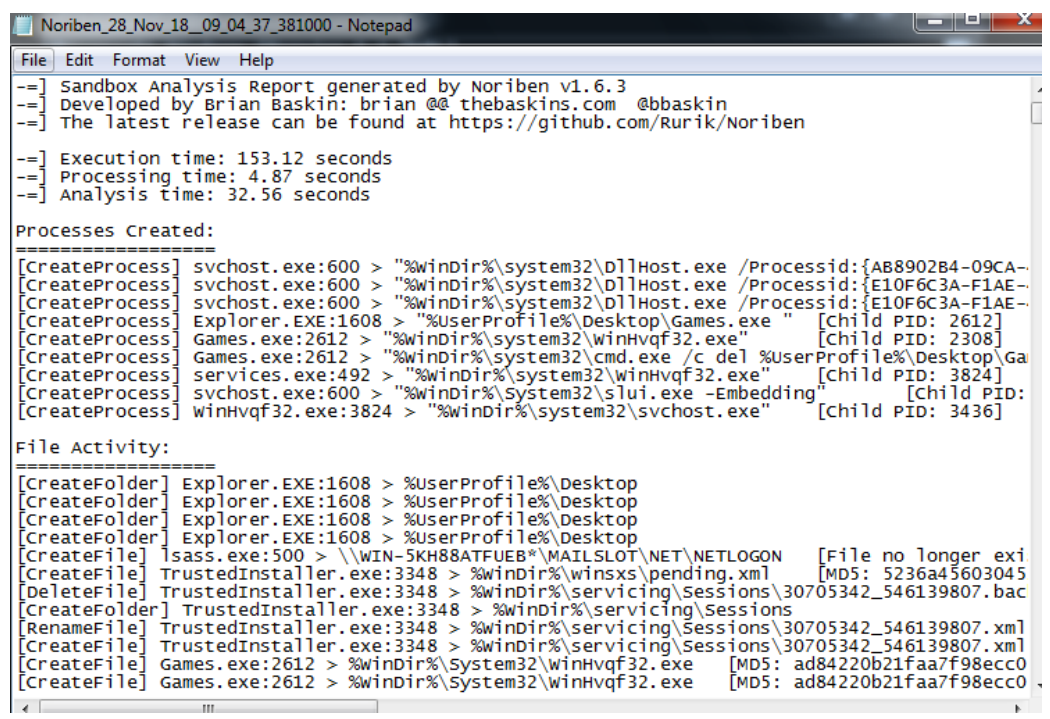

Gambar 8. Hasil monitoring Noriben

Hasil dari Analisa Noriben menunjukan pada Proceses created adanya proses WinHvqf32.exe ketika file Games.exe dijalankan dan file tersebut meminta layanan svchost.exe (Generic Host Process untuk Win32 Services) yang merupakan bagian integral dari OS Windows untuk melalui layanan services yang mana layanan tersebut dapat melakukan Automatic Update, hal ini menjadi mungkin bagi file Games.exe untuk mengakses jaringan. Pada file activity juga menampilkan adanya aktivitas pembuatan file WinHvqf32.exe oleh file Games.exe yang memiliki md5 sama persis di lokasi system32. Ada yang menarik dengan file ini, ketika di cari secara biasa kita tidak akan bias menemukannya, karena filenya di super hidden atau di sembunyikan dengan sangat baik, sehingga meskipun pengaturan show hidden folder, file, and driver sudah diaktifkan, file tetap tidak muncul dan terlihat, dari itu kita 


\section{Journal of Software Engineering Ampera}

Vol. 1, No. 3, October 2020 e-ISSN: 2775-2488

https://journal-computing.org/index.php/journal-sea/index

menggunakan trik tambahan untuk menampilkan file yang sudah di super hidden dengan cara masuk ke cmd, ketikan "dir/ah" dan enter, seluruh file akan tampil semua termasuk yang telah di hidden. Selanjutnya kita akan menampilkan file tersebut di windows explorer karena meskipun sudah tampil di cmd, file tersebut belum tampil pada windows explorer. Cara menampilkannya yaitu dengan menggunakan perintah "attrib" dan diiringi dengan nama file.

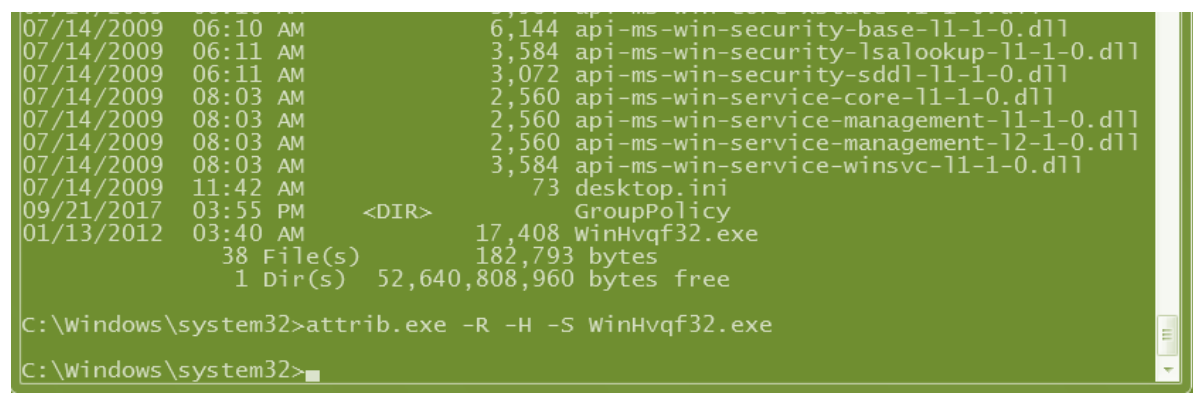

Gambar 9. Menampilkan file hidden

5) Monitoring paket data pada jaringan menggunkan Wireshark

Hasil monitoring yang dilakukan Wireshark ketika file Games.exe dieksekusi pada system opersi windows telah menagkap adanya komunikasi yang dilakukan oleh IP 192.168.206.2 kepada 192.168..208.225 menggunakan protocol NBNS dan meminta layanan ke alamat wWW.1533ss.com.

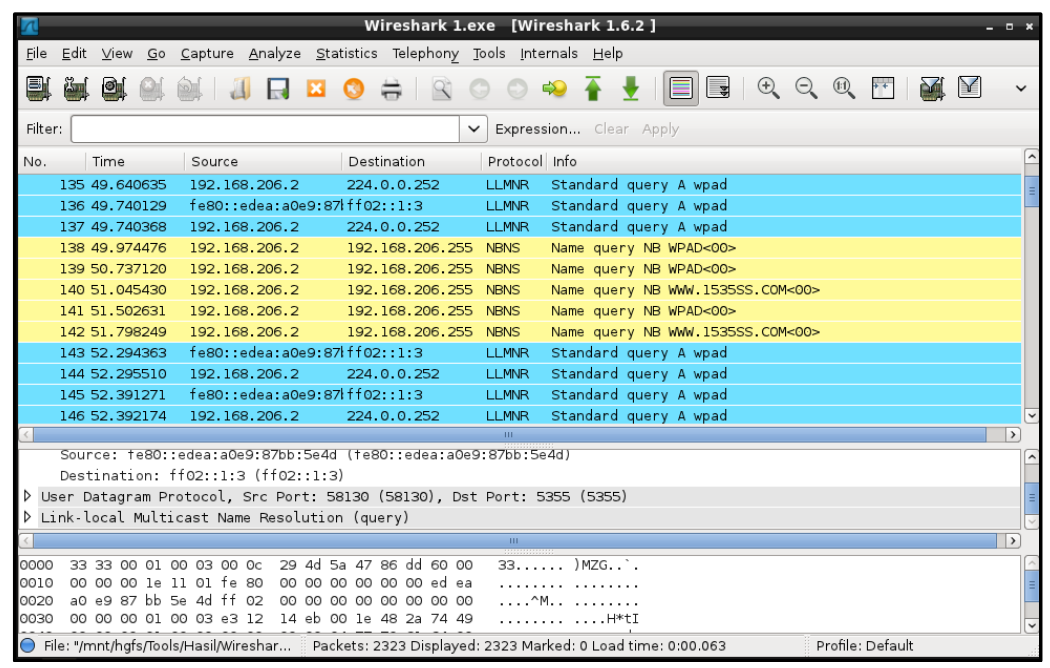

Gambar 10. Wireshark 


\section{Journal of Software Engineering Ampera}

Vol. 1, No. 3, October 2020 e-ISSN: 2775-2488

https://journal-computing.org/index.php/journal-sea/index

Tabel 1. Hasil Analisa dan pengujian perilaku malware menggunakan metode Surface Analysis

\begin{tabular}{|c|c|c|c|c|}
\hline \multirow{2}{*}{$\mathrm{N}$} & \multirow{2}{*}{$\begin{array}{l}\text { Tahapa } \\
\mathrm{n}\end{array}$} & \multicolumn{3}{|l|}{ Surface Analysis } \\
\hline & & Tool & \multicolumn{2}{|c|}{ Hasil Temuan } \\
\hline \multirow{5}{*}{1} & \multirow{5}{*}{$\begin{array}{l}\text { File } \\
\text { Attribu } \\
\text { te } \\
\text { analysi } \\
\mathrm{s}\end{array}$} & \multirow{5}{*}{ Pestudio } & $\begin{array}{l}\text { File } \\
\text { Name }\end{array}$ & Games.exe \\
\hline & & & MD5 & $\begin{array}{l}\text { AD84220B21FAA7F98ECC05C504 } \\
\text { ACD7B7 }\end{array}$ \\
\hline & & & $C P U$ & 32-bit \\
\hline & & & Type & executable \\
\hline & & & $\begin{array}{l}\text { Indicato } \\
\text { rs }\end{array}$ & $4 / 14$ \\
\hline \multirow{5}{*}{2} & \multirow{5}{*}{$\begin{array}{l}\text { Phacke } \\
\text { rs } \\
\text { Check }\end{array}$} & \multirow{5}{*}{ Exeinfo } & \multicolumn{2}{|c|}{$\begin{array}{l}\text { UPX } 0.89 \text { - 3.xX -> Markus \& Laszlo ver. [ } \\
3.95 \text { ] }\end{array}$} \\
\hline & & & \multicolumn{2}{|c|}{$\begin{array}{l}\text { unpack "upx.exe -d" from http://upx.sf.net } \\
\text { or any UPX/Generic unpacker }\end{array}$} \\
\hline & & & \multicolumn{2}{|l|}{ text } \\
\hline & & & \multicolumn{2}{|l|}{ rdata } \\
\hline & & & \multicolumn{2}{|l|}{ data } \\
\hline \multirow[b]{2}{*}{3} & \multirow{2}{*}{$\begin{array}{l}\text { Fuzzy } \\
\text { Hashin } \\
g\end{array}$} & Md5sum & \multicolumn{2}{|l|}{ Sama } \\
\hline & & ssdeep & \multicolumn{2}{|l|}{$100 \%$} \\
\hline \multirow{11}{*}{4} & \multirow{11}{*}{$\begin{array}{l}\text { Analisa } \\
\text { Strings }\end{array}$} & \multirow{2}{*}{ Pestudio } & \multicolumn{2}{|l|}{$101 / 272$} \\
\hline & & & \multicolumn{2}{|c|}{ www.1535ss.com } \\
\hline & & & \multicolumn{2}{|c|}{ OpenSCManager } \\
\hline & & & \multicolumn{2}{|c|}{ WININET.dII } \\
\hline & & & \multicolumn{2}{|l|}{ http:// } \\
\hline & & & \multicolumn{2}{|l|}{ HTTP } \\
\hline & & Yara dan Strings & \multicolumn{2}{|c|}{ ExitProcess } \\
\hline & & & \multicolumn{2}{|c|}{ CreateProcess } \\
\hline & & & \multicolumn{2}{|c|}{ InternetOpenUrI } \\
\hline & & & \multicolumn{2}{|l|}{ Sleep } \\
\hline & & & \multicolumn{2}{|c|}{ GetSystemDirectory } \\
\hline 5 & $\begin{array}{l}\text { Malwa } \\
\text { re Scan }\end{array}$ & $\begin{array}{l}\text { wWw.virustotal. } \\
\text { com }\end{array}$ & \multicolumn{2}{|c|}{ Worm dan Trojan } \\
\hline
\end{tabular}




\section{Journal of Software Engineering Ampera}

Vol. 1, No. 3, October 2020 e-ISSN: 2775-2488

https://journal-computing.org/index.php/journal-sea/index

Tabel 2. Hasil Analisa dan pengujian perilaku malware menggunakan metode Runtime Analysis

\begin{tabular}{|c|c|c|c|c|c|c|}
\hline \multirow[b]{2}{*}{$\begin{array}{l}N \\
0\end{array}$} & \multirow[b]{2}{*}{ Temuan } & \multicolumn{5}{|c|}{ Runtime Analysis } \\
\hline & & $\begin{array}{l}\text { Regsh } \\
\text { ot }\end{array}$ & $\begin{array}{l}\text { Proces } \\
\text { s } \\
\text { Hacke } \\
r\end{array}$ & $\begin{array}{l}\text { CaptureB } \\
\text { AT }\end{array}$ & $\begin{array}{l}\text { Noribe } \\
n \\
\text { Sanbo } \\
x\end{array}$ & $\begin{array}{l}\text { Wiresha } \\
\text { rk }\end{array}$ \\
\hline & $\begin{array}{l}\text { Penambahan } \\
\text { registry }\end{array}$ & $\checkmark$ & - & $\checkmark$ & $\checkmark$ & - \\
\hline & $\begin{array}{l}\text { Penambahan file } \\
\text { baru pada } \\
\text { C:IWindows } \text { syste } \\
\text { m32 }\end{array}$ & $\checkmark$ & - & $\checkmark$ & $\checkmark$ & - \\
\hline & File hidden & - & - & $\checkmark$ & $\checkmark$ & - \\
\hline & $\begin{array}{l}\text { Alamat IP/web } \\
\text { Program : } \\
\text { www.1535ss.com }\end{array}$ & - & - & - & - & $\checkmark$ \\
\hline & $\begin{array}{l}\text { Nomor Port yang } \\
\text { digunakan : } 8080\end{array}$ & - & - & - & - & $\checkmark$ \\
\hline & $\begin{array}{l}\text { Protocol yang } \\
\text { digunakan ; NBNS }\end{array}$ & - & - & - & - & $\checkmark$ \\
\hline & $\begin{array}{l}\text { File yang berjalan } \\
\text { dilatar belakang }\end{array}$ & - & $\checkmark$ & - & - & - \\
\hline
\end{tabular}

\section{KESIMPULAN}

Berdasarkan analisa dan pengujian terhadap sampel Games.exe maka didapatlah kesimpulan diantaranya:

1) File Games.exe jelas dapat dikatakan sebuah malware dikarenakan memiliki strings yang pada umumnya terdapat pada sebuah malware.

2) Melakukan penambahan dan membuat sebuah perubahan pada registry 


\section{Journal of Software Engineering Ampera}

Vol. 1, No. 3, October 2020 e-ISSN: 2775-2488

https://journal-computing.org/index.php/journal-sea/index

3) File dapat menggandakan diri ke folder system32 dengan menjadi file WinHvqf32.exe yang dibuktikan dengan kesamaan MD5 pada file tersebut.

4) File dapat menyembunyikan dirinya dengan menghapus file utama dan melakukan hidden pada file duplikat.

5) File juga melakukan interaksi pada jaringan dengan melakukan akses ke website www.1535ss.com.

6) Dari kesemua tools yang digunakan, Noriben merupakan tool yang paling baik dalam menganalisa sebuah file.

7) Dari hasil scan yang dilakukan menggunakan virus total menunjukan bahwa md5 dari file Games.exe belum tercatat sebagai malware.

8) Dapat disimpulkan bahwa file Games.exe merupakan sebuah malware jenis Botnet, Trojan dan Worm atau virus menurut perilakunya.

\section{DAFTAR PUSTAKA}

[1] Adenansi, R., dan Novarina, L. A. (2017). "Malware dynamic". JoEICT (Journal of Education And ICT), 1(1).

[2] Agung, M. F. (2011). "Pengertian serta penjelasan metode secara umummengenai Malware Analysis". Konsep Dasar Malware Analysis.

[3] Indrajit, R. E., 2012. "Analisa Malware". E-Artikel Sistem Dan Teknologi Informasi.

[4] Nurdiyanto, W. (2013). "Skenario Kombinasi Tools yang Efektif dalam Analisis

Malware". http://pusdiklat.bps.go.id/index.php?r=artikel/view\&id=248. Diakses 20/09/2018.

[5] Perdhana, M. R. (2011). "Analisa Malware Harmless Hacking" (Cetakan pertama ed.). Yoyakarta: Graha IImu.

[6] Sugiyono (2012). Metode Penelitian Kuantitatif Kualitatif dan R\&D. Bandung: Alfabeta. 